\title{
Wymiary męskości
}

\author{
Urszula Kluczyńska ${ }^{1}$ \\ Uniwersytet Medyczny im. Karola Marcinkowskiego w Poznaniu \\ Katarzyna Wojnicka \\ Centrum Badań Europejskich Uniwersytetu w Göteborgu
}

$\mathrm{Na}$ przełomie lat sześćdziesiątych i siedemdziesiątych XX wieku w Ameryce Północnej, Europie Zachodniej i Australii zaczęły rozwijać się studia męskie (men's studies). Ich założyciele uważali się za kontynuatorów myśli feministycznej, a prowadzone z tej perspektywy badania miały na celu pogłębienie analizy nad męskością i męskim doświadczeniem jako specyficznym w swych społecznych, kulturowych i historycznych wymiarach. Studia te stały się z czasem zbyt pojemną kategorią i profeministyczni badacze zaproponowali zastąpienie zbyt ogólnego terminu, precyzyjniejszym - krytyczne studia nad mężczyznami (critical studies on men), by tym sposobem podkreślić, że powstają one „na skutek wielu rodzajów krytyki - przede wszystkim feministycznej, ale także ze strony przedstawicieli naukowej perspektywy gejowsko-lesbijskiej, oraz jako odpowiedź samych mężczyzn, zwłaszcza mężczyzn profeministów, na feminizm i debaty dotyczące relacji genderowych" (Hearn 2004: 49-50).

Przełomem - istotnym dla rozwoju studiów nad mężczyznami - była krytyka tradycyjnej roli męskiej prowadzona przez Josepha Plecka (1981) i uwagi tego badacza dotyczące szkodliwości narzuconych stereotypowych męskich ról. Tim Carrigan, Bob (Raewyn) Connell i John Lee (1987) poszli krok dalej, stwierdzając, że męska rola (the male sex role) nie istnieje, jest daleko idącym uproszczeniem, ponieważ niemożliwe jest wyizolowanie roli, która konstruuje męskość (lub kobiecość).

Kolejną koncepcją, która wywarła wpływ na sposób myślenia i analizowania męskości, jest koncepcja męskości hegemonicznej, którą australijska badaczka, Connell, przybliżyła między innymi

\footnotetext{
${ }^{1}$ Autorka korespondencyjna: Urszula Kluczyńska, Uniwersytet Medyczny im. K. Marcinkowskiego, Katedra i Zakład Edukacji Medycznej, ul. Dąbrowskiego 79, 60-529 Poznań, email: ulakluczynska@umed.poznan.pl, ulaklu@wp.pl
}

No. 10 / 2015

wymiary męskości 
w klasycznej już pracy "Masculinites” (2005). Autorka zaproponowała hierarchiczną typologię wzorców męskości właściwych dla szeroko pojmowanej kultury zachodniej. Wytwarzane i redefiniowane męskości odnoszone są do pewnego normatywnego wzorca męskości, który Connell określiła jako męskość hegemoniczną (hegemonic masculinity). Owo podejście jest współcześnie szeroko stosowane w analizach męskości, ale także poddawane krytyce. Chris Beasley (2011) krytycznie odnosi się do braku różnorodności pod względem teorii umożliwiających analizy w obrębie studiów i wskazuje teorię męskości hegemonicznej jako przykład perspektywy, która zmonopolizowała sposób myślenia o męskościach i cytowana jest w niemal każdym artykule na ten temat. Badaczka zauważa też, że wśród naukowczyń i naukowców z zakresu studiów nad mężczyznami dominuje podejście socjologiczne, przede wszystkim konstrukcjonizm społeczny.

Odnosząc się do wspomnianej teorii męskości hegemonicznej, Eric Anderson (2009) wskazał na funkcjonowanie - jego zdaniem - dwóch uznawanych współcześnie wersji męskości. Jedną określił mianem ortodoksyjnej, a zatem wysoce homofobicznej i mizoginicznej, a drugą włączającej, będącej przeciwieństwem tej pierwszej. Teoria męskości włączającej (inclusive masculinity theory) zakłada, że zmniejszenie poziomu homofobii (MacCormak 2012) powoduje, iż różne formy męskości mogą funkcjonować w horyzontalnym, a nie hierarchicznym porządku. Ponadto jedna lub więcej form męskości włączającej może dominować liczbowo, co nie oznacza ich hierarchicznej dominacji.

Studia nad mężczyznami i męskościami rozwinęły się bardzo dynamicznie w latach dziewięćdziesiątych ubiegłego wieku, obejmując swoim zasięgiem głównie kraje Europy Zachodniej, Stany Zjednoczone i Australię. Wśród "klasyków” i "klasyczek” zajmujących się tematyką męskości - poza wspomnianą wcześniej Connell - których wkład w rozwój studiów nad mężczyznami i męskościami jest niepodważalny, można wymienić między innymi: Michaela Kimmela, który podejmuje tematykę męskich ruchów społecznych, kryzysów męskości, pornografii; Michaela Messnera, skupiającego się głównie na tematyce sportu i ciała mężczyzn; Dona Sabo, który podejmuje problematykę męskości w kontekście spotu, zdrowia i więziennictwa; a także Michaela Flooda, zajmującego się kwestiami męskiej seksualności oraz relacjami rodzinnymi; Martina Mac an Ghaill'a skupiającego się na tematyce edukacji i seksualności; Jeffa Hearna, który poruszając kwestie związane z problematyką męskości, skupia się między innymi na przemocy mężczyzn; Chris Beasley analizującej między innymi kwestię seksualności. Większość współczesnych 
teorii i badań nad mężczyznami i przemianami męskości jest autorstwa anglojęzycznych badaczek i badaczy, a publikacje w innych językach, w tym polskim, stanowią niewielki procent wkładu w dotychczasowy dorobek studiów.

Jednocześnie od kilku lat grono polskich naukowczyń i naukowców konsekwentnie prowadzi analizy nad problemami wchodzącymi w skład omawianej perspektywy, walcząc o status podejścia, które nadal wydaje się być marginalizowane w dyskursie naukowym. Studia nad mężczyznami i męskościami nie są "wygodne" - i to na różne sposoby, ponieważ są to przede wszystkim studia krytyczne. Badaczki i badacze stawiają pytania, które burzą tradycyjny sposób myślenia o rzeczywistości społecznej i porządku genderowym, opisują mechanizmy zmian, prowokują do myślenia. Studia te nie koncentrują się wyłącznie na męskościach hegemonicznych, obszarem analiz są także męskości marginalizowane, wykluczane, oraz indywidualne sposoby (re)definiowania męskości. Takie podejście powoduje, że metodologia badań ma często (choć nie tylko) charakter jakościowy, a naukowa refleksja nad fenomenami męskości, choć silnie związana jest z perspektywą socjologiczną, ma wymiar interdyscyplinarny.

Zdaniem Beasley (2011) wśród najczęściej analizowanych w obrębie omawianej dziedziny kwestii dominują te związane w problematyką rynku pracy, zdrowia, przemocy czy edukacji, podczas gdy problematyka seksualności zdaje się być niemal niedostrzegana. Chcąc w pewnym stopniu wypełnić tę lukę, proponujemy - wraz z autorkami i autorami artykułów składających się na tom czasopisma - numer specjalny "InterAliów” zatytułowany: "Wymiary męskości”, łączący problematykę krytycznych studiów nad męskościami i mężczyznami ze studiami nad seksualnością, queer i gender. Sądzimy, że współczesne studia nad mężczyznami i męskościami wymagają nie tylko krytycznej analizy przedmiotu/podmiotu swych badań, ale również swojego miejsca w obrębie i w stosunku do innych obszarów badawczych.

Zbiór artykułów otwiera tekst Wojciecha Śmiei, który analizuje utwory Jana Żyznowskiego i skupia się na wątku męskiej cielesności/sprawności i męskości. Analizy demitologizują okaleczenia wojenne i ukazują je jako wyraz kryzysu dominującej tradycyjnej, militarystycznej męskości.

W drugim artykule Sława Grzechnik opisuje proces kształtowania męskiego habitusu pod wpływem praktyk komunikacyjnych reprodukowanych w klasie szkolnej. Autorka, wykorzystując teorię 
społeczną Pierre'a Bourdieu oraz koncepcję ujarzmiania podmiotu Michela Foucaulta, analizuje akty performatywne oraz sposób użycia języka w polu szkoły i ukazuje, jak dochodzi do nadawania znaczeń w przestrzeni kształtowania się męskiego habitusu i socjalizacji genderowej.

Trzeci artykuł, autorstwa Bartka Lisa, dotyczy wątku męskich przyjaźni w sytuacji, gdy jeden z podmiotów jest mężczyzną homoseksualnym, a zatem sytuacji, które są współcześnie szczególnie nadzorowane. Wychodząc z założeń o mitycznej przyjaźni braterskiej, a dochodząc do współczesnego rekonfigurowania kategorii męskiej romantycznej przyjaźni między mężczyznami, autor wskazuje, jak homofobia wpłynęła na konstrukcję i jakość męsko-męskich nieerotycznych, nieseksualnych relacji. Lis ukazuje, że doszło nie tylko do zwiększenia fizycznego dystansu i rywalizacji między mężczyznami, ale także do takiego przedefiniowania podstaw męskiej przyjaźni, by niemożliwe było realizowanie lub choćby podejrzenie homoseksualnych pragnień.

W czwartym artykule Mateusz Kobryn przedstawia teorie odnoszące się do mechanizmów społecznego konstruowania tożsamości płciowej, które przedstawiają męskość jako społecznie (re)konstruowany zestaw scenariuszy gotowych do odegrania przez mężczyznę i odnosi je do praktyki psychoterapii psychoanalitycznej. Skupia się na relacji psychoterapeuty z grupą mężczyzn niewpisujących się w heteronormatywny schemat: osobach transseksualnych, homoseksualnych i "niemęskich mężczyznach". Autor zastanawia się nad "prawidłowym” przebiegiem procesu identyfikacji płciowej w kontekście optymalnego funkcjonowania w społeczeństwie i wolności jednostki w wyborze własnej seksualności, ale również w kontekście oddziaływań psychoterapeuty.

Tekst Urszuli Kluczyńskiej porusza tematykę medykalizacji seksualności mężczyzn i również odnosi się do kwestii normy. Artykuł przybliża sposób, w jaki medycyna kontroluje i normalizuje seksualność oraz wyjaśnia i proponuje rozwiązania „problemów” związanych z seksualnością. Autorka skupia się na kwestii medykalizacji homoseksualności i transseksualności, a także ukazuje sposób, w jaki dyskurs medyczny kontroluje męskie ciała oraz seksualności i redukuje rozumienie seksualności do praktyk seksualnych i falliczności. Wskazuje też, jak dyskurs medyczny uwzniośla binarny podział ciał, seksualności i orientacji seksualnej. Krytycznym odczytaniem medycznej interpretacji normy, seksualności i męskości stara się ukazać, jak heteronormatywny porządek pomija inne opcje, które tym sposobem „znikają”. 
Zakwestionowana we wcześniejszym artykule prawomocność „normy” i binarnego podziału znajduje swoistą kontynuację w tekście Anny Kłonkowskiej. Autorka wychodząc z perspektywy konstrukcjonizmu społecznego, prezentuje wyniki badaniach jakościowych przeprowadzonych wśród osób transpłciowych, dotyczące orientacji seksualnej. Kłonkowska ukazuje jak - jej zdaniem przeniesienie binarnych kategorii męskość/kobiecość, heteroseksualność/homoseksualność stosowanych powszechnie wobec osób cispłciowych do osób transpłciowych utrzymuje określony ład społeczny, a stosowanie owych konstrukcji ma charakter normatywizujący.

W siódmym artykule Justyna Struzik analizuje, jak aktywiści ruchów queerowych konstruują swoją męskość. W rozważaniach teoretycznych, wykorzystując genderowe soczewki, skupia się na relacji między konstruowaniem płci a działaniami kolektywnymi, oraz odnosi do kwestii wytwarzania seksualności. Analizy te są wprowadzeniem ułatwiającym zrozumienie sposobu przekraczania i negocjowania granic męskości w obrębie ruchów queerowych, wyłaniającym się z badań jakościowych przeprowadzonych przez autorkę wśród aktywistów i aktywistek ruchów queerowych w Polsce.

Podobnie jak Struzik, także autorka kolejnego tekstu - Iwona Stasik - odniosła się do polityczności tożsamości płciowej. Stasik zastosowała metodę etnograficzną: przeprowadziła wywiady pogłębione z czterema przedstawicielkami polskiej sceny drag kingowej, jak również poddała analizie treści 55 nagrań z występami drag kingów. W ramach analiz autorka stara się odpowiedzieć na pytanie, czy występy drag kingów są formą zabawy, kampem czy zaangażowaniem politycznym.

Zbiór tekstów zamyka artykuł Rafała Majki, który analizując gejowską postsubkulturę bareback, pokazuje, jak mężczyźni homoseksualni mogą reinterpretować pasywność w kontaktach seksualnych i wyjść "z heteronormatywnych binarnych ram uległej i »zniewieściałej« pasywności naprzeciw dominującej, męskiej aktywności" (Majka 2015). Autor ukazuje, w jaki sposób może dochodzić do redefiniowania męskości, seropozytywności, pasywności i dominacji. Proponuje on odczytanie postsubkultury bareback i pornografii typu bareback jako krytykę hegemonicznego instytucjonalnego systemu społecznego. 
Zapraszamy Państwa do lektury. Dziękujemy redakcji „InterAliów” za udostępnienie przestrzeni i możliwość zredagowania tomu "Wymiary męskości", a autorkom i autorom tekstów za udział w przedsięwzięciu.

\section{BIBLIOGRAFIA}

Anderson, Eric. 2009. Inclusive Masculinity: The Changing Nature of Masculinities. New York: Routledge.

Beasley, Chris. 2011. Gender \& Sexuality. Critical theories, critical thinkers. Los Angeles, London, New Delhi, Singapore, Washington: Sage.

Brod, Harry. 1987. The making of masculinities. The new men's studies. London, Sidney, Wellington: Allen \& Unwin.

Brod, Harry. 1987. A Case for Men's Studies. W: (red.) Kimmel, Michael. Changing Men. New Direction in Research on Men and Masculinity. Newbury, London, New Delhi: Sage, s. 263277.

Carrigan, Tim, Connell, Bob, Lee John. 1987. Toward the new sociology of masculinity. W: (red.) Brod, Harry. The making of masculinities. The new men's studies. London, Sidney, Wellington: Allen \& Unwin, s. 63-100.

Connell, R. W. 1987. Gender and Power: Society, the Person and Sexual Politics. Sydney: Allen \& Unwin.

Connell, Raewyn. 2005. Masculinities. Sydney: Allen \& Unwin.

Connell, R. W. 2000. The Men and the Boys. Sydney: Allen \& Unwin.

Hearn, Jeff. 2004. From hegemonic masculinity to the hegemony of men. "Feminist Theory" $5:$ 49-72.

McCormak, Mark. 2012. The Declining Significance of Homophobia: How Teenage Boys are Redefining Masculinity and Heterosexuality. New York: Oxford University Press.

Pleck, Joseph H. 1981. The myth of masculinity. Cambridge, London: The MIT Press. 